\title{
Atmospheric Trajectory and Chemical Transport Modelling for Elevated Ozone Events in Denmark
}

\author{
Alexander Mahura ${ }^{1^{*}}$, Roman Nuterman ${ }^{1,2}$, Irina Petrova ${ }^{3,4}$, Bjarne Amstrup $^{1}$ \\ ${ }^{1}$ Danish Meteorological Institute (DMI), Copenhagen, Denmark \\ ${ }^{2}$ Tomsk State University (TSU), Tomsk, Russia \\ ${ }^{3}$ Russian State Hydrometeorological University (RSHU), St. Petersburg, Russia \\ ${ }^{4}$ Now at University of Hamburg, Max Planck Institute for Meteorology, Hamburg, Germany \\ Email: *ama@dmi.dk
}

Received May 22, 2012; revised June 24, 2012; accepted July 1, 2012

\begin{abstract}
In this study, three Danish sites having the longest (1990-2004) time-series of ozone measurements were analysed on inter-annual, monthly and diurnal cycle variability as well as elevated and lowered ozone concentration events were identified. The atmospheric trajectory (HYSPLIT) and dispersion (HIRLAM + CAMx) models were employed to study dominating atmospheric transport patterns associated with elevated events and to evaluate spatio-temporal variability of ozone specific episode and typical seasonal patterns for Denmark. It was found that generally inter-annual variability has a positive trend, and events with low ozone concentration $\left(\leq 10 \mu \mathrm{g} / \mathrm{m}^{3}\right)$ continued to diminish. On a monthly scale, the highest and lowest mean concentrations are observed in May and November-December, respectively. The elevated concentrations $\left(\geq 120 \mu \mathrm{g} / \mathrm{m}^{3}\right)$ are observed during March-September. On a diurnal cycle, it is observed mostly during 13-16 of local time, and more frequent (ten-fold) compared with nighttime-early morning hours. For ozone elevated events, several sectors (or pathways of atmospheric transport) were identified depending on the sites' positions, showing the largest (39\%) number of such events associated with the north-western sector, and lowest (13\% each) - southwestern and northern sectors. For each site, less than 60 events showed very high concentrations $\left(\geq 180 \mu \mathrm{g} / \mathrm{m}^{3}\right)$. Among 12 episodes, one longest elevated episode (19-21 Jun 2000) simultaneously registered at all sites and characterized by dominating transport from the south-southwestern sector, low wind speed, clear-sky, and multiple inversions was studied using modelling tools. For this episode, both measurements and modeling (trajectory and dispersion) results showed a relatively good agreement.
\end{abstract}

Keywords: Elevated Ozone Concentration Event and Episode; Atmospheric Trajectory; Chemical Transport Modeling; HYSPLIT; HIRLAM; CAMx

\section{Introduction}

Ozone $\left(\mathrm{O}_{3}\right)$ is one of the pollutants of the major concern for population and environment, and its high levels are an indicator of high pollution representing significant risks to humans, flora, fauna [1], as well as economic damage [2]. For several decades ozone has been operationally forecasted by many countries. It has been analyzed to get insight on local and regional trends, daily, seasonal and inter-annual variability, spatial and temporal distribution. Ozone is a natural component of the troposphere, produced by photochemical reactions of nitrogen oxides $\left(\mathrm{NO}_{\mathrm{x}}=\mathrm{NO}+\mathrm{NO}_{2}\right)$ and volatile organic compounds (VOCs) emitted from local and remote anthropogenic and biogenic sources. Once it has been produced it could exist in the troposphere for several days. Close to anthropogenic sources such as industrial or highly urban-

"Corresponding author. ized areas, emitted $\mathrm{NO}$ may react to form $\mathrm{NO}_{2}$, and hence, to reduce ozone locally. Therefore, generally maximum concentration and exposure to ozone pollution will occur downwind of the sources [3], e.g. in suburban and rural areas. However, for some regions with specific topography and under certain synoptical conditions air masses can re-circulate and stay within a region for longer period of several days.

The major mechanisms responsible for elevated ozone during heat-wave episode included horizontal transport from continental Europe with existence of a long-lived anticyclone, convergence of westerly and easterly nearsurface winds, or downward entrainment of ozone-rich air from residual layers in the free troposphere [4]. Ozone production highly depends on meteorological conditions including sunlight, cloudiness, temperature, and wind characteristics [5]. Ozone measured at specific site may be produced many hundred kilometres away. It 
can be transported from elsewhere in the world because intercontinental ozone transport is an efficient process [6]. Even application of various policy options for ozone precursors may still remain a significant potential for photochemical ozone formation and long-range transport [7]. Episodes of high ozone concentrations are the most interest; and these are based on a sum of existing regional background ozone levels, stratospheric ozone injections, and contribution of ozone produced in troposphere from naturally occurring and man-made precursors.

In Denmark, automatic ozone measurements are performed by the Danish National Environment Research Institute (NERI) in selected urban and rural areas. Such data are publically available at the European Monitoring and Evaluation Programme (EMEP; http://www.emep.int) website. In general, instruments record the regional background level for Denmark, but also, on occasion, pollution transported from sources outside of the country.

In this study, the long-term (1990-2004) time-series of ozone measurements at 3 sites have been analysed on inter-annual, monthly and diurnal cycle variability as well as cases with elevated and lowered concentrations were identified. Atmospheric trajectory and dispersion modelling tools were applied to study dominating atmospheric transport patterns associated with elevated ozone events and spatial and temporal variability of concentration patterns for selected episodes and on a seasonal scale for Denmark $[8,9]$.

\section{Methodology}

\subsection{Ozone Measurements}

The available original time-series of ozone measurements at three selected Danish sites-DK31 $\left(56.28^{\circ} \mathrm{N}, 08.43^{\circ} \mathrm{E}\right.$; Ulborg), DK32 $\left(55.97^{\circ} \mathrm{N}, 12.33^{\circ} \mathrm{E}\right.$; Frederiksborg), and DK41 $\left(55.69^{\circ} \mathrm{N}, 12.13^{\circ} \mathrm{E}\right.$; Lille Valby) covered a period from 1990 to 2004. Two of these sites (DK41 and DK32) are located on the Zealand island and one site (DK31) is placed on the Jutland Peninsula (Figure 1(a)) of Denmark. After pre-screening and removing all missing and below detection limit values, the total number of available measurements for analysis had been reduced (Table 1). Each record included information on a value of concentration and corresponding temporal parameters (year, month, day, hour of measurement).

General statistics from analysis of the revised timeseries showing a number of the cases with different elevated (i.e. above 120,150 , and $180 \mu \mathrm{g} / \mathrm{m}^{3}$ ) and lowered ozone concentrations (i.e. below $10 \mu \mathrm{g} / \mathrm{m}^{3}$ ) as well as years with highest and lowest number of such cases in selected years for three sites is summarized in Table 1.

As seen, during the period studied the absolute maximum value of concentration was above $200 \mu \mathrm{g} / \mathrm{m}^{3}$ for all

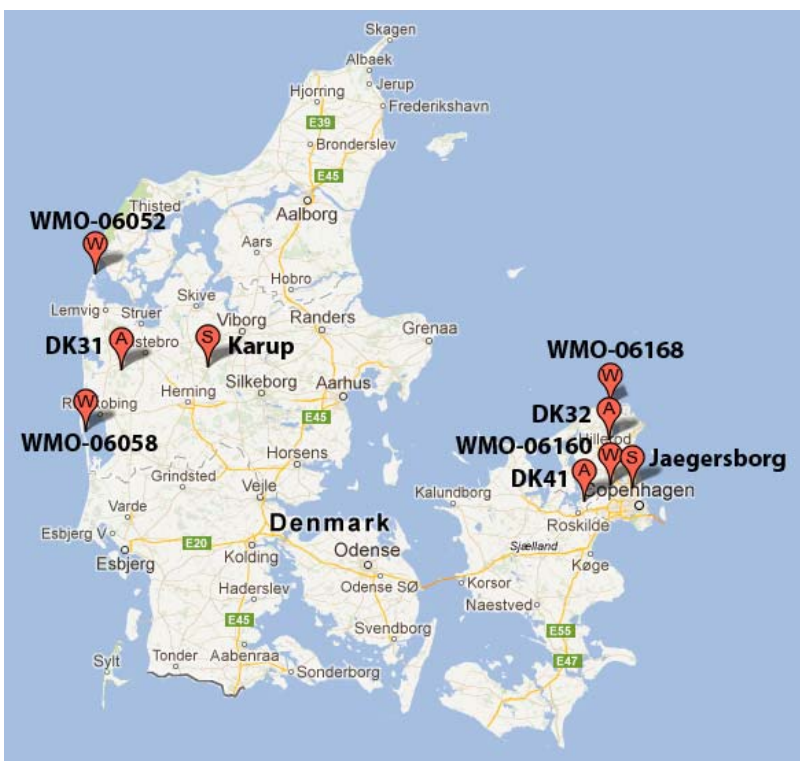

(a)

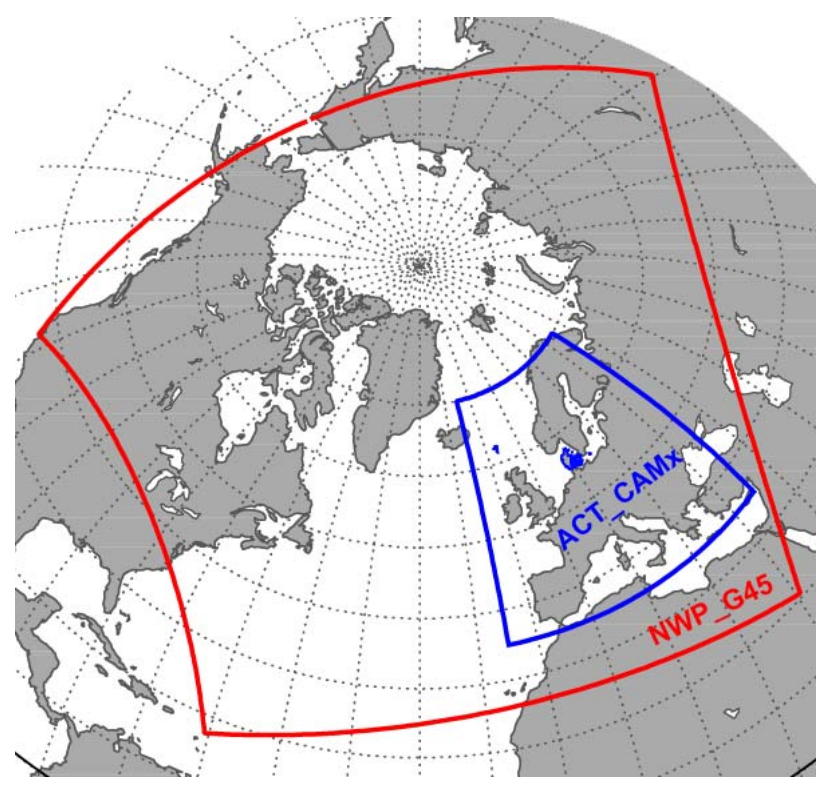

(b)

Figure 1. (a) Geographical positions (extracted from GoogleEarth) of Danish sites for ozone measurements (A: DK31, DK32, and DK41), synoptical meteorological stations (W: WMO-06160-Vaerlose, WMO-06168-Nakkehoved Fyr, WMO-06058-Hvide Sande, WMO-06052 - Thyboron) and sounding stations (S: Jaegersborg, Karup); and (b) Boundaries of domains for atmospheric (NWP_G45) and chemical transport (ACT-CAMx) modelling.

3 sites. The elevated ozone levels were registered only in about $1.5 \%$ and less than $1 \%$ of the cases for the DK31 and DK41, DK32 sites, respectively. Note that ozone levels above $120 \mu \mathrm{g} / \mathrm{m}^{3}$ were registered practically in all years analyzed, but very high levels (above $180 \mu \mathrm{g} / \mathrm{m}^{3}$ ) were observed only in 5 years from all 15 years considered. Note that observed peaks in ozone concentration 
Table 1. Summary statistics on a number of the cases $(N)$ with ozone concentration levels (above 120, 150, and 180, and below $10 \mu \mathrm{g} / \mathrm{m}^{3}$ ) for three Danish measurement sites (H-highest, L-lowest).

\begin{tabular}{cccc}
\hline $\begin{array}{c}\text { Measurement Site } \\
\text { Parameter }\end{array}$ & DK-31 & DK-41 & DK-32 \\
\hline Original \# measurements & 131495 & 122735 & 105192 \\
Revised \# measurements & $115690(100 \%)$ & $115447(100 \%)$ & $97939(100 \%)$ \\
$\mathrm{N}\left(\mathrm{O}_{3}>120 \mu \mathrm{g} / \mathrm{m}^{3}\right)$ & $1745(1.5 \%)$ & $1079(0.9 \%)$ & $811(0.8 \%)$ \\
$\mathrm{H}(\mathrm{N}-\mathrm{year})$ & $221-1992$ & $212-1992$ & $199-1992$ \\
$\mathrm{~L}(\mathrm{~N}-\mathrm{year})$ & $41-1998$ & $10-2001$ & $22-1991$ \\
$\mathrm{~N}\left(\mathrm{O}_{3}>150 \mu \mathrm{g} / \mathrm{m}^{3}\right)$ & 206 & 161 & 140 \\
$\mathrm{H}(\mathrm{N}-\mathrm{year})$ & $41-2000$ & $45-1992$ & $38-1992$ \\
$\mathrm{~L}(\mathrm{~N}-\mathrm{year})$ & $1-1998$ & $1-1996 / 1998$ & $1-1999$ \\
$\mathrm{~N}\left(\mathrm{O}_{3}>180 \mu \mathrm{g} / \mathrm{m}^{3}\right)$ & 36 & 42 & 31 \\
$\mathrm{H}(\mathrm{N}-\mathrm{year})$ & $15-2000$ & $15-1992$ & $11-1992$ \\
$\mathrm{~L}(\mathrm{~N}-\mathrm{year})$ & $1-2001$ & $2-1997 / 1999$ & $2-1994$ \\
$\mathrm{~N}\left(\mathrm{O}_{3}<10 \mu \mathrm{g} / \mathrm{m}^{3}\right)$ & $2990(2.6 \%)$ & $8732(7.6 \%)$ & $8464(8.6 \%)$ \\
$\mathrm{H}(\mathrm{N}-\mathrm{year})$ & $370-1997$ & $994-1997$ & $980-1990$ \\
$\mathrm{~L}(\mathrm{~N}-\mathrm{year})$ & $55-2003$ & $399-2001$ & $366-2001$ \\
$\mathrm{Abs} \mathrm{Max} \mathrm{O}_{3}, \mu \mathrm{g} / \mathrm{m}^{3}$ & $221(1990)$ & $213(1992)$ & $213(1992)$ \\
\hline
\end{tabular}

are dependent on regional background levels of ozone, specific rate of photochemical production during a day, and contribution of other chemical species (such as nitric oxide and VOCs) to ozone related chemical reactions. In addition, both local and remote sources and on occasion, stratospheric ozone injections could play an important role. The lowered ozone levels were observed more frequently (up to $8.6 \%$ ), and a number of such cases was larger for sites of the Zealand compared with Jutland regions.

\subsection{Atmospheric Trajectory Modelling}

The backward trajectory modelling is a widely used tool for evaluation of possible atmospheric transport to geographical locations where short- or long-term measurements of chemical species are conducted. The tracking of air parcels spatial positions in the atmosphere during such transport can allow identifying potential paths and regions from where pollution can be transported and associated. The accuracy of the trajectories is typically of the order of $20 \%$ of the travelling distance, although in some cases it can be larger [10].

In our study, the National Oceanic and Atmospheric Administration (NOAA) on-line transport and dispersion Hybrid Single-Particle Lagrangian Integrated Trajectory model (HYSPLIT) v 4.5 model available in an interactive mode http://www.arl.noaa.gov/ready/open/hysplit4.html) was used [11,12]. HYSPLIT performs computing of both forward and backward types of trajectories using several methods. To drive trajectory simulations the gridded meteorological dataset (http://dss.ucar.edu/pub/reanalysis) NCEP/NCAR Global Reanalysis 1948-Present-was used [13]. It has temporal coverage 4 times per day $(00,06,12$, 18 UTCs), including daily and monthly values from 1
Jan 1948 to present. Spatial coverage includes entire globe. There are 17 pressure level and 28 sigma levels.

Each computed trajectory was associated with the corresponding elevated ozone measurement at one of the three sites. For simplicity, only one trajectory arriving at the measurement sites at the ground level for term with the highest value of concentration was computed backward in time up to 120 hours (5 days) using vertical motion calculation method. This duration was selected because of the residence time of ozone in the atmosphere which is leading to a characteristic scale of its atmospheric transport of $1000 \mathrm{~km}$. A set of meteorological data was also extracted along each trajectory at 6 hour intervals. It included the terrain height, potential temperature, air temperature, precipitation, relative humidity, and mixing layer height. Because there is a difference of 1 hour between the universal coordinated time (UTC) and Danish LST, the trajectories were computed at corrected times in order to fit the corresponding measurements done at local times. Then all trajectories were grouped depending on pathway of atmospheric transport and area from where trajectories have arrived.

\subsection{Meteorological and Chemical Transport Modelling}

\subsubsection{Meteorological Modelling}

The Numerical Weather Prediction (NWP) models (with their 3D meteorological output) are used as drivers for the Atmospheric Chemistry Transport (ACT) models. The selection of meteorological driver as well as boundaries for domain of interest will depend of specific application. Hence, different meteorological operational or reanalyzed archived datasets from NWP can be used. Output from operational and climatological models can be 
used in different applications.

Danish Meteorological Institute (DMI) runs several nested versions of the HIRLAM (http://hirlam.org) model with horizontal resolution ranging from 15 to $3 \mathrm{~km}$ and forecast length up to 72 hours. Moreover, there is urbanized version of HIRLAM model (resolution $1.5 \mathrm{~km}$ ) run in a research mode for environmental applications. The operational DMI forecasting modelling system [14,15] includes the pre-processing, climate file generation, data assimilation, initialization, forecasting, post-processing, and verification. It includes also a digital filtering initialization, semi-Lagrangian advection scheme, and a set of physical parameterizations such as Savijaervi radiation [16], STRACO condensation [15], CBR turbulence scheme [17], and ISBA land surface scheme [18]. The lateral boundary conditions are received every 6 hour from European Center for Medium-Range Weather Forecasts (ECMWF). The system is running on the DMI CRAYXT5 supercomputer and produced output is archived on a mass storage system. In our study, the DMI-HIRLAMG45 model $(45 \times 45 \mathrm{~km}, 31$ vertical levels $)$ was run to produce 3D meteorological fields (see domain in Figure 1(b)).

\subsubsection{Chemical Transport Modelling}

The chemical transport modelling is based originally on the CAMx (Comprehensive Air quality Model with extensions) model (http://www.camx.com) with built an interface between NWP (DMI-HIRLAM-G45) and ACT (modified CAMx, v 4.4) models. Through interface necessary information was extracted from the NWP model output, and then it served as input for the ACT model. The Carbon Bond IV (CB-IV) Mechanism [19] with is used. This mechanism is used together with the Tropospheric Ultraviolet and Visible (TUV) radiation model [20] to calculate photolysis rate coefficients. The modelling system is used to simulate aerosols and gas-phase compounds from different scales of ground-level gasphase air pollutants. It can be used for air quality forecasts and modelling of historical data.

The horizontal and vertical resolutions of the ACT model depend on a resolution of the used meteorological and emission data. The selected ACT-CAMx domain (Figure 1(b)) includes the European countries with Denmark in the center. It has a horizontal resolution of $0.2^{\circ} \times$ $0.2^{\circ}$ (appx. $20 \times 20 \mathrm{~km}$ ) and 25 vertical levels including 15 HIRLAM levels covering the lowest $3 \mathrm{~km}$ of the troposphere. The amount of chemical compounds, which is transported from the free troposphere into the atmospheric boundary layer, is determined by the meteorological information and concentration of chemical compounds in the free tropospheric. These concentrations depend on the longitude, latitude, land/ sea mask and month of the year. The TNO MEGAPOLI emission inventory [21] $\left(0.06^{\circ} \times 0.12^{\circ}\right.$ resolution $)$ had been interpolated into grids of the ACT model taking into account vertical distribution. In order to reach a chemical equilibrium, a 2 day spin up has been applied, and the forecast length extended up to 24 hours.

Moreover, in order to study the chemical transport and links with dominating meteorological conditions, it is necessary to analyze in more details the available surface maps, vertical sounding diagrams, and observations at synoptical meteorological stations (Figure 1(a)) located near the ozone measurement sites.

\section{Results and Discussions}

\subsection{Observed Inter-Annual, Monthly and Diurnal Variability}

Analysis of inter-annual variability (during the period studied 1990-2004) of ozone time-series showed generally a positive trend of ozone increase (Figure 2(a)). The number of cases with lowered ozone concentration levels (i.e. below $10 \mu \mathrm{g} / \mathrm{m}^{3}$, see Figure 2(b)) continued to decease throughout the period of measurements, and it occurs more rapidly for sites located on the Zealand Island (DK32 and DK41) compared with DK-31 site on the Jutland Peninsula. In general, for a period of more than 10 years, the number of such cases decreased almost twice.

Month-to-month variability of the mean ozone concentration show clear differences between the sites (Figure 2(c)). As seen, throughout the year, the higher mean ozone levels are observed for the DK31 site, compared with others; and the lower-for DK32 site. The highest mean concentrations are characteristic in May for all sites, and for DK31 site it is the largest of about $80 \mu \mathrm{g} / \mathrm{m}^{3}$. The mean concentrations are the lowest in November-December, decreasing to about 40 and $30 \mu \mathrm{g} / \mathrm{m}^{3}$ for the DK31 and DK32, DK41 sites, respectively. The elevated concentrations (i.e. more than $120 \mu \mathrm{g} / \mathrm{m}^{3}$ ) are observed during March-September (Figure 2(d)). Throughout the mentioned period the number of such cases is larger for the DK31 site compared with two others. The maximum number of such cases is in August for DK31 and DK41 sites, compared with DK32 - in June.

On a diurnal cycle, all sites showed similar shape of variability with a maximum occurred at about midday (14 hour of the local time) and a minimum - in the morning (at 06 hour) (Figure 2(e)). A shape of such diurnal variability is due to high reactivity of ozone. Concentration at the surface level is decreased rapidly in evening hours (although it could remain elevated above the mixing layer and then contribute to elevated ozone levels in the following days). In time-series, the absolute ozone maxima (considering levels of above $120 \mu \mathrm{g} / \mathrm{m}^{3}$ ) are observed mostly during $13-16$ hours, and the number of such cases is ten-fold larger compared with nighttime- 


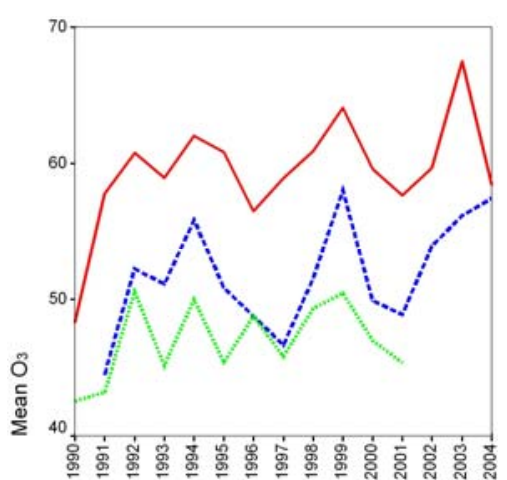

(a)

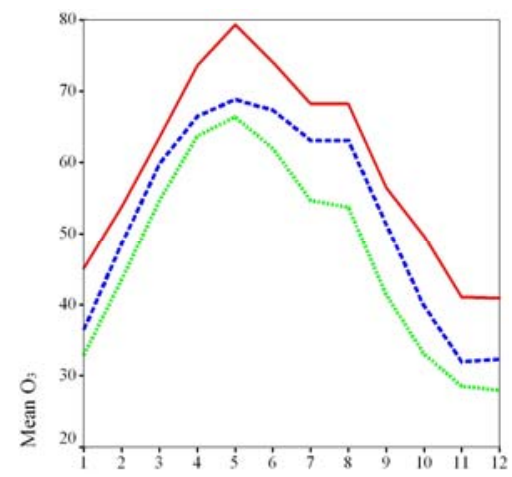

(c)

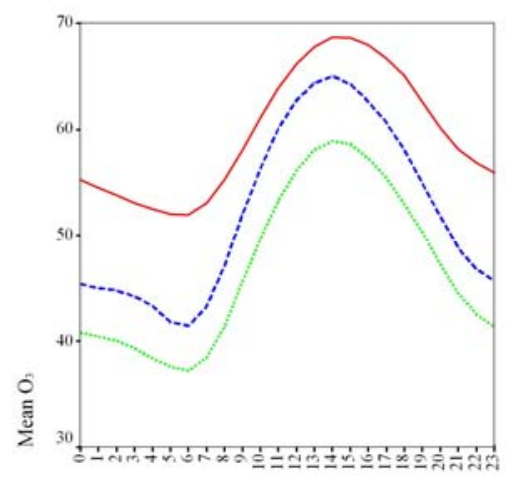

(e)

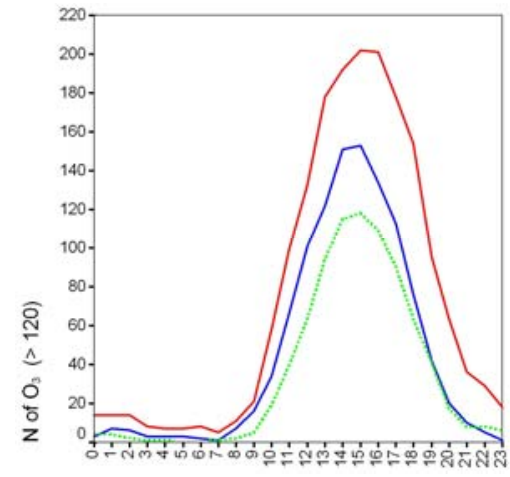

(g)

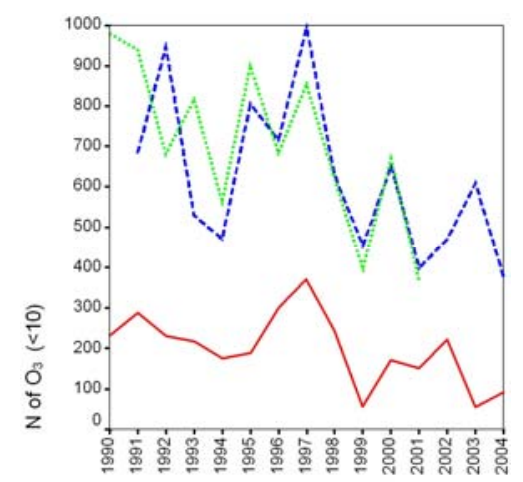

(b)

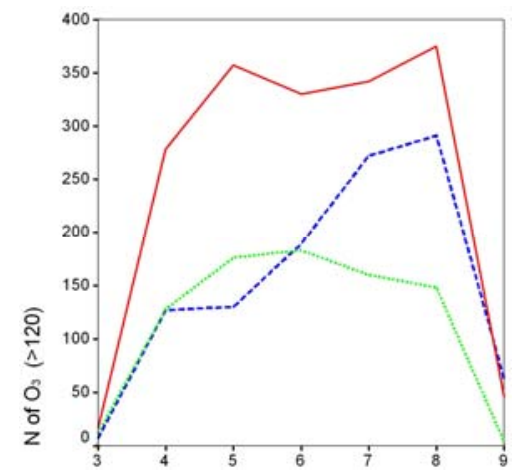

(d)

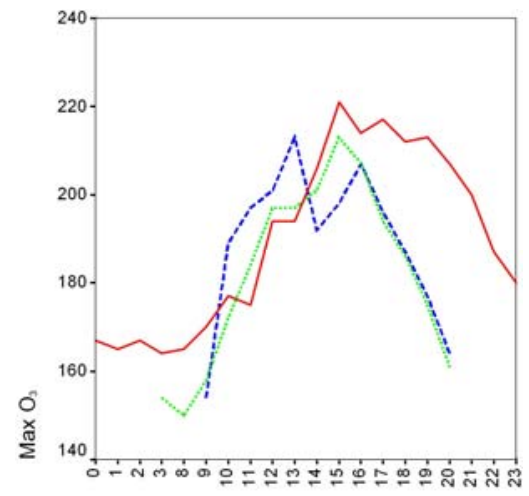

(f)

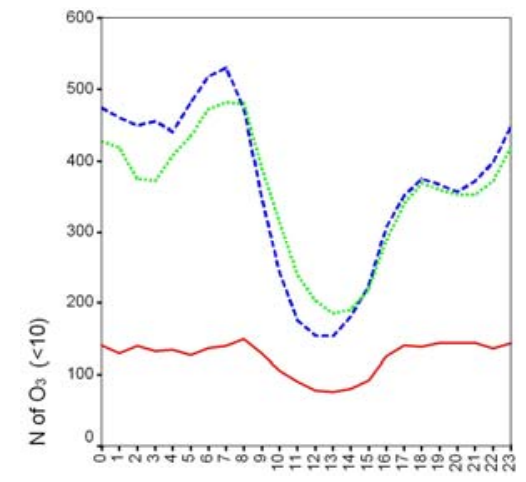

(h)

Figure 2. Ozone inter-annual ((a) and (b)), monthly ((c) and (d)) and diurnal cycle ((e)-(h)) variability for the mean concentration in $\mu \mathrm{g} / \mathrm{m}^{3}$ ((a), (c) and (e)), absolute maximum concentration (f), number of cases with concentrations below $10 \mu \mathrm{g} / \mathrm{m}^{3}$ ((b) and (h)) and above $120 \mu \mathrm{g} / \mathrm{m}^{3}((\mathrm{~d})$ and $(\mathrm{g}))$ for three Danish sites DK31 (- $\left.{ }^{-}\right)$, DK32 (…), and DK41 (---- ). 
early morning hours (Figures 2(f) and (g)). The number of the cases with the lowest ozone concentration (less than $10 \mu \mathrm{g} / \mathrm{m}^{3}$ ) varied from about 100 (DK31) to 200 (DK32) cases during $11-15$ hours, and it was up to 3 times higher during late evening-nighttime hours for the Zealand sites, but almost non-variable for the Jutland site (Figure 2(h)).

Note that on figures for the mean ozone concentration (i.e. Figures 2(a), (c) and (e)) the similar pattern of higher ozone concentrations on inter-annual, monthly, and diurnal cycle scales exists for the DK31 site compared with two other locations.

\subsection{Atmospheric Transport Sectors and Pathways}

Distribution of trajectories (number and percentage) arrived at three measurement sites during 1990-2004 by sectors and pathways, linked with atmospheric transport, is summarized in Table 2. As seen, the clustering of trajectories revealed 7 possible atmospheric transport pathways divided into sectors (i.e. from where trajectories have arrived). In total, 207, 139, and 160 trajectories were associated with elevated ozone events observed at the DK31, DK32, and DK42 measurement sites, respectively.

The largest number of trajectories connected with such events was associated with the North-West sector (in total 155 trajectories). Trajectories from this sector are all originated over the Atlantic Ocean aquatoria. But there are several paths of such transport through: 1) UK, Benelux countries, and Germany; 2) UK and North Sea (only for DK31 site; 9 trajectories); 3) Norway and North Sea; and 4) Benelux countries and Germany. The first path dominates among others (more than 20 trajectories per each site). The smallest number of trajectories was associated with the South-West sector (where trajectories also originated over Atlantic Ocean, but additionally passed over France and Benelux countries before reaching Denmark) for DK31 and DK32 sites, and with the North sector-for DK41 site.
Trajectories, arriving at the three measurement sites from the North sector, are all originated over Scandinavian countries (Norway and Sweden). There are two possible comparable paths of such transport through: 1) Baltic Sea and Poland/Germany (28 trajectories); and 2) Baltic Sea (26 trajectories). Note, that the first path is more characteristic for the DK31 site (18 trajectories), but the second path is almost equally (about 8 trajectories per site) observed at all three sites.

Atmospheric transport from the South sector (through Germany/Benelux countries) is the second largest (accounting for 81 cases). Moreover, some trajectories did not show clear pathway of atmospheric transport (i.e. had complex structure and circulated over Denmark) and these were assigned to "no clear identification" category. In total, this category includes 34 trajectories (out of 506).

Several examples of simulated backward trajectories associated with elevated ozone arriving at sites underline dominating direction of atmospheric transport of air parcels toward the measurement sites' locations (as seen in Figure 3). In figures a distance between marked $12 \mathrm{~h}$ intervals shows approximate speed of such transport. The changing spatial position of trajectory shows movement of air parcels through possible source regions. For example, as seen in Figure 3(a), air parcels arriving at the DK41 site, located on the Zealand Island, originated from the Atlantic Ocean aquatoria 5 days before. These have traveled through the UK metropolitan and industrial areas as well as the North Sea on its way to Denmark. This pathway is associated with atmospheric transport from the South-West sector. Figure 3(b) depicts that air parcels arrived at the DK31 site, located on the Jutland Peninsula, originated over Benelux countries and heavily populated and industrialized Rein-Ruhr area (Germany). This example is associated with atmospheric transport from the South sector. Figure 3(c) presents transport from the East sector. In particular, the trajectories originnated over the North-West Russia passed through the Baltic States and aquatoria of the Baltic Sea before reaching the DK31 site.

Table 2. Summary (number and percentage) of trajectories arrived at 3 ozone measurement sites during 1990-2004 by sectors and pathways of atmospheric transport.

\begin{tabular}{|c|c|c|c|c|c|}
\hline \multirow{2}{*}{ Sector } & \multirow{2}{*}{ N traj by sector } & \multirow{2}{*}{ Pathway } & \multicolumn{3}{|c|}{ \% of trajectories by site } \\
\hline & & & DK31 & DK32 & DK41 \\
\hline $\mathbf{E}$ & 71 & $\mathrm{BST}(\mathrm{RU}) \rightarrow$ Sea $\rightarrow$ PL $\rightarrow(\mathrm{GE})$ & 12.1 & 11.5 & 18.6 \\
\hline SW & 43 & $\mathrm{AO} \rightarrow \mathrm{FR} \rightarrow \mathrm{Blux} / \mathrm{GE}$ & 5.8 & 7.9 & 12.5 \\
\hline SE & 68 & PL/GE & 6.8 & 22.4 & 14.4 \\
\hline NW & 155 & From $\mathrm{AO} \rightarrow$ & 38.7 & 24.4 & 25.7 \\
\hline $\mathbf{N}$ & 54 & From Scandinavia $\rightarrow$ & 13.1 & 10.8 & 7.5 \\
\hline \multirow[t]{3}{*}{ NOID } & 34 & No clear identification & 6.7 & 1.4 & 11.3 \\
\hline & & total $\%$ of trajectories by site & 100 & 100 & 100 \\
\hline & 506 & total number of trajectories & 207 & 139 & 160 \\
\hline
\end{tabular}

Comment: AO_Atlantic Ocean; BST_-Baltic States; RU—Russia; PL_Poland; GE_-Germany; FR—France; Blux-Benelux countries; Scand.—Scandinavian countries (Norway/Sweden). 


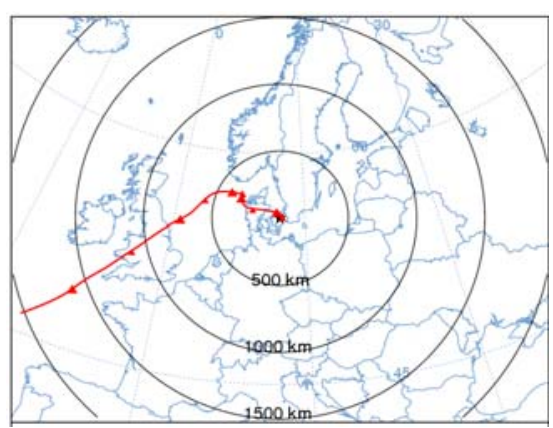

(a)

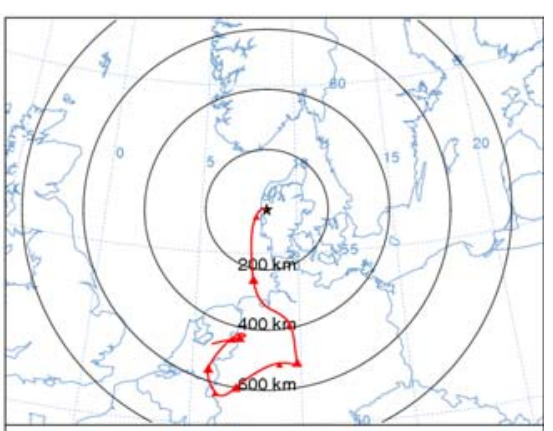

(b)

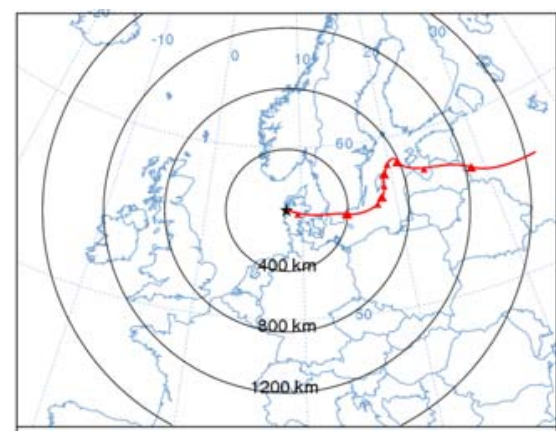

(c)

Figure 3. Backward trajectories (calculated by the NOAA HYSPLIT model) showing atmospheric transport from the (a) South-West sector arrived at DK41 on 30 Jul 1994, 15 UTC; (b) South sector arrived at DK31 on 6 Jun 1996, 18 UTC; and (c) East sector arrived at DK31 on 2 Jun 1992, 14 UTC.

The obtained distribution (as a function of the sector and pathway for the atmospheric transport) of trajectories (associated with elevated ozone has underlined a strong variability between 3 locations (Table 2). Depending on the positions of the measurement sites, up to $18 \%$ of elevated events are associated with transport from the eastern sector, up to $13 \%$ - from the south-west, up to $22 \%$ from the south, up to $22 \%$ - from the south-east, up to $39 \%$ - from the north-west, up to $13 \%$-from the north; with some trajectories having no clear identification. Among trajectories there are those passing through inland (i.e. through the Baltic States, Russia, Poland, Germany, France, Benelux and Scandinavian countries) as well as water areas (i.e. transport from the Atlantic Ocean, Baltic and North Seas).

\subsection{Elevated Concentration Episodes}

Several episodes with elevated levels were identified from detailed analysis of multi-year ozone time-series. For such episodes the level of concentration depends on both the local conditions and due to long-range transport contribution. The following criteria were chosen: 1) concentration higher $150 \mu \mathrm{g} / \mathrm{m}^{3} ; 2$ ) observed, at least, during 24 hours period; 3) simultaneously, at least, at two measurement sites; and 4) associated with one of the potential source regions (i.e according to identified sectors of atmospheric transport (see Ch. 3.2). There were 7, 6 and 5 relatively long-term episodes for the DK31, DK32, and DK41 sites, respectively. The ranking of these episodes is the following: 1) 19-21 Jun 2000 and 30 Jun-1 Jul 1992 - occurred at 3 sites simultaneously; 2) 4 Aug 1990, 9-10 Aug 1992, 26-28 Jul 1994 and 5 May 1995-occurred at 2 sites simultaneously; and 3) 28 Jul 1995, 6-8 Jun 1996, 6 Aug 1999 and 16 May 2000-occurred at one of the sites. Although elevated concentrations were also observed in other months, but duration of episodes was very short. One episode with the longest duration (i.e. 19-21 Jun 2000) was selected for detailed analysis em- ploying the HIRLAM + CAMx modeling system.

\subsection{Case Study-Episode for 19-21 June 2000}

During 19-21 Jun 2000 elevated ozone episode, in the Danish studied area the typical meteorological conditions near the surface were characterized by dominating winds (with low speeds up to $5 \mathrm{~m} / \mathrm{s}$ ) from the south-southwestern sector (associated with Benelux countries and Germany). Although wind conditions in this sector were similar to Danish but it had been warmer there. During the episode the air temperature varied $16^{\circ} \mathrm{C}-30^{\circ} \mathrm{C}$ (sector) compared with $14^{\circ} \mathrm{C}-24^{\circ} \mathrm{C}$ (Denmark). Most time it was cloud-free and become partly cloudy on the last day of the episode. The relative humidity ranged from $48 \%$ to $97 \%$ on Jutland and from $41 \%$ to $99 \%$ on Zealand. The twice daily sounding diagrams from the Jægersborg (on Zealand) and Karup (on Jutland) stations showed the presence of several inversions in the low layers (some originated at the surface and some at higher altitudes, and extended up to $850 \mathrm{hPa}$ ). Moreover, on a preceding day (i.e. 18 Jun 2000) to the episode the isothermal layers were also observed at $600-650 \mathrm{hPa}$ levels. The wind patterns remained of the south-southwestern sector and dominated within the boundary layer up to $850 \mathrm{hPa}$ (with speeds up $5-10$ and $5-15 \mathrm{~m} / \mathrm{s}$ for the Jægersborg and Karup stations, respectively).

The elevated ozone episode in June 2000 started at 12 UTC on 19 June 2000 (see Figure 4(a)), i.e. when ozone concentration became above $150 \mu \mathrm{g} / \mathrm{m}^{3}$ at DK31 site.

Then, concentration rapidly increased at this site reaching more than $200 \mu \mathrm{g} / \mathrm{m}^{3}$ within a few hours. Due to atmospheric transport the plume with elevated ozone levels reached the DK32 site around 08 UTC on 20 Jun 2000, and a few hours later - the third site DK41. On this day from 10 UTC, the elevated concentrations were recorded at all three sites simultaneously. On the same day at about $16 \mathrm{UTC}$, the absolute maxima 194 and $207 \mu \mathrm{g} / \mathrm{m}^{3}$ were observed at DK32 and DK41 sites, respectively. Both 
maxima were observed almost a day later after the maximum at the DK31 site. Then, the concentration gradually decreased at all three locations, and this episode has ended after 17 UTC on 21 Jun 2000 (i.e. when concentration become below $\left.150 \mu \mathrm{g} / \mathrm{m}^{3}\right)$.

As seen in Figures 4(b)-(d), the atmospheric transport toward three measurements sites have occurred from the South-Western sector, i.e. mostly from the industrial and urbanized areas of the Benelux countries and northwestern parts of the Rein-Ruhr region. Before arrival in Denmark during 3 days the air masses travelled mostly within the atmospheric boundary layer and passed over these regions getting additional ozone load.

An example of the CAMx simulated chemical transport patterns (Figure 5) is given on one of the days of the selected episode (nighttime-noon on 19 June 2000) with output provided at every 12 hour interval.

At nighttime, the ozone concentration is below 30 $\mu \mathrm{g} / \mathrm{m}^{3}$ over the most area of the European domain, including Denmark and it had started to increase during morning hours reaching more than $130 \mu \mathrm{g} / \mathrm{m}^{3}$ at noon in the northern territories of Germany and Jutland Peninsula of Denmark where the DK31 site is located. The timeseries shows almost similar value of measurements (150 $\mu \mathrm{g} / \mathrm{m}^{3}$ ), which underlines that the CAMx model showed relatively good performance, although some discrepancies can be attributed to a relatively low horizontal resolution of the model run (i.e. when peaks in concentration associated with specific location will be smoothed over grid-cell). For comparison of elevated ozone concentration episode, the typical monthly concentration patterns for June 2000 are shown in Figure 6(a) (see explanation in Ch. 3.5).

\subsection{Modelled Monthly, Seasonal and Annual Patterns Authors and Affiliations}

The simulated monthly-averaged typical atmospheric chemical transport pattern (characteristic for the June 2000) over the European domain is shown in Figure 6(a). As seen, during June the ozone concentration over Denmark varied, on average, between $50 \mu \mathrm{g} / \mathrm{m}^{3}$ (for northern territories of Denmark) and $60 \mu \mathrm{g} / \mathrm{m}^{3}$ (southern territories

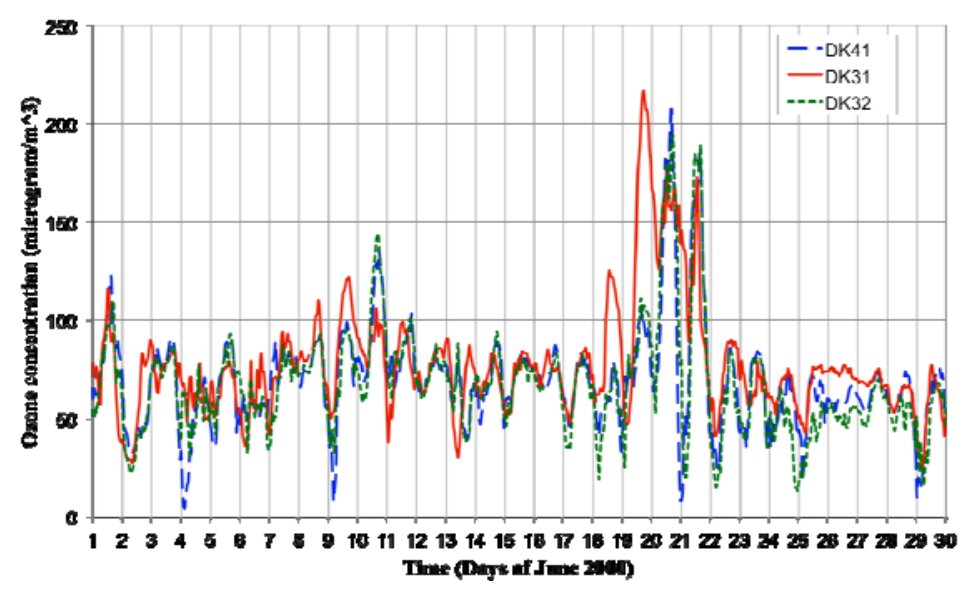

(a)

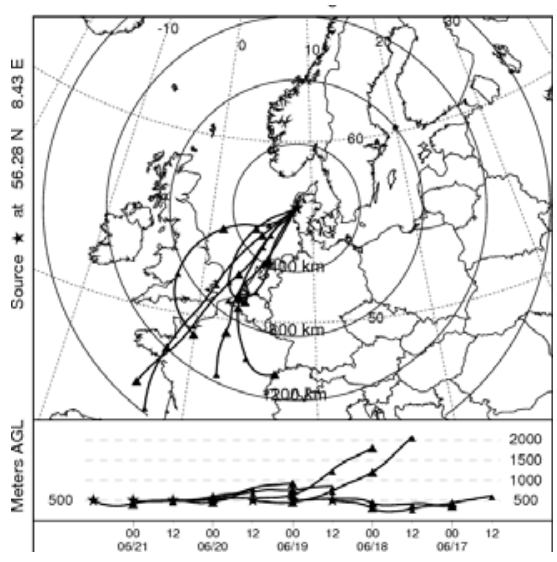

(b)

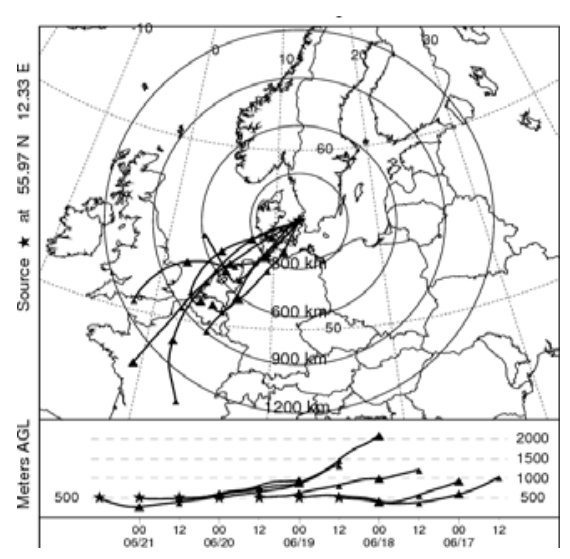

(c)

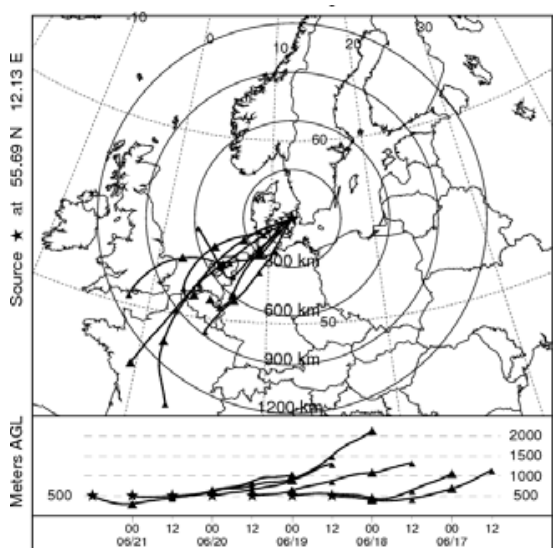

(d)

Figure 4. (a) Time-series of ozone measurements at 3 sites during Jun 2000; and (b)-(d) ensemble of backward trajectories arriving at (b) DK31; (c) DK32; and (d) DK41 sites during 19-21 Jun 2000. 


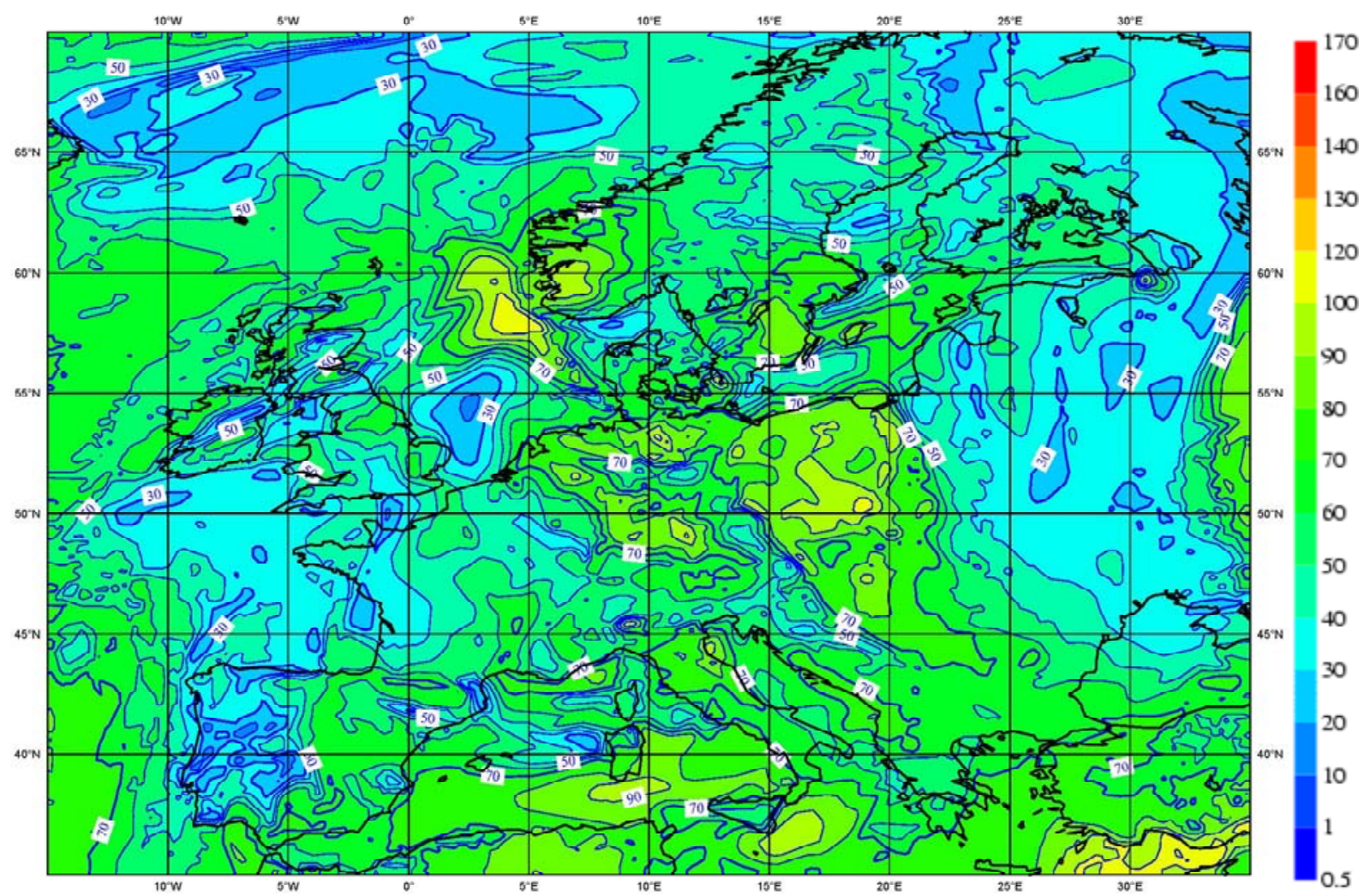

(a)

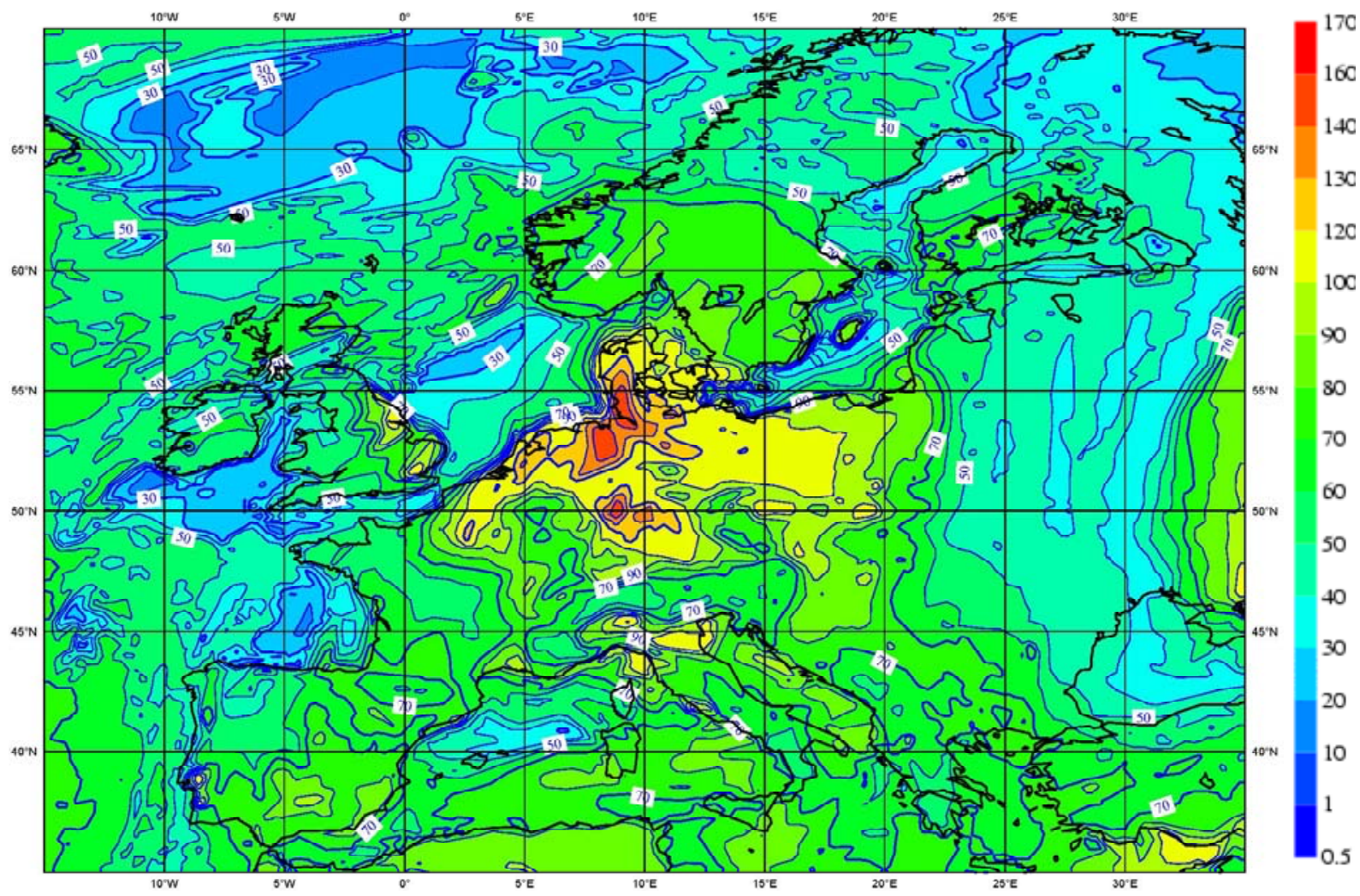

(b)

Figure 5. Spatial distribution of ozone concentration (in $\mu \mathrm{g} / \mathrm{m}^{3}$ ) field for $19 \mathrm{Jun} 2000$ ((a) and (b): at nighttime-noon; 00-12 UTC) (simulated by HIRLAM + CAMx). 


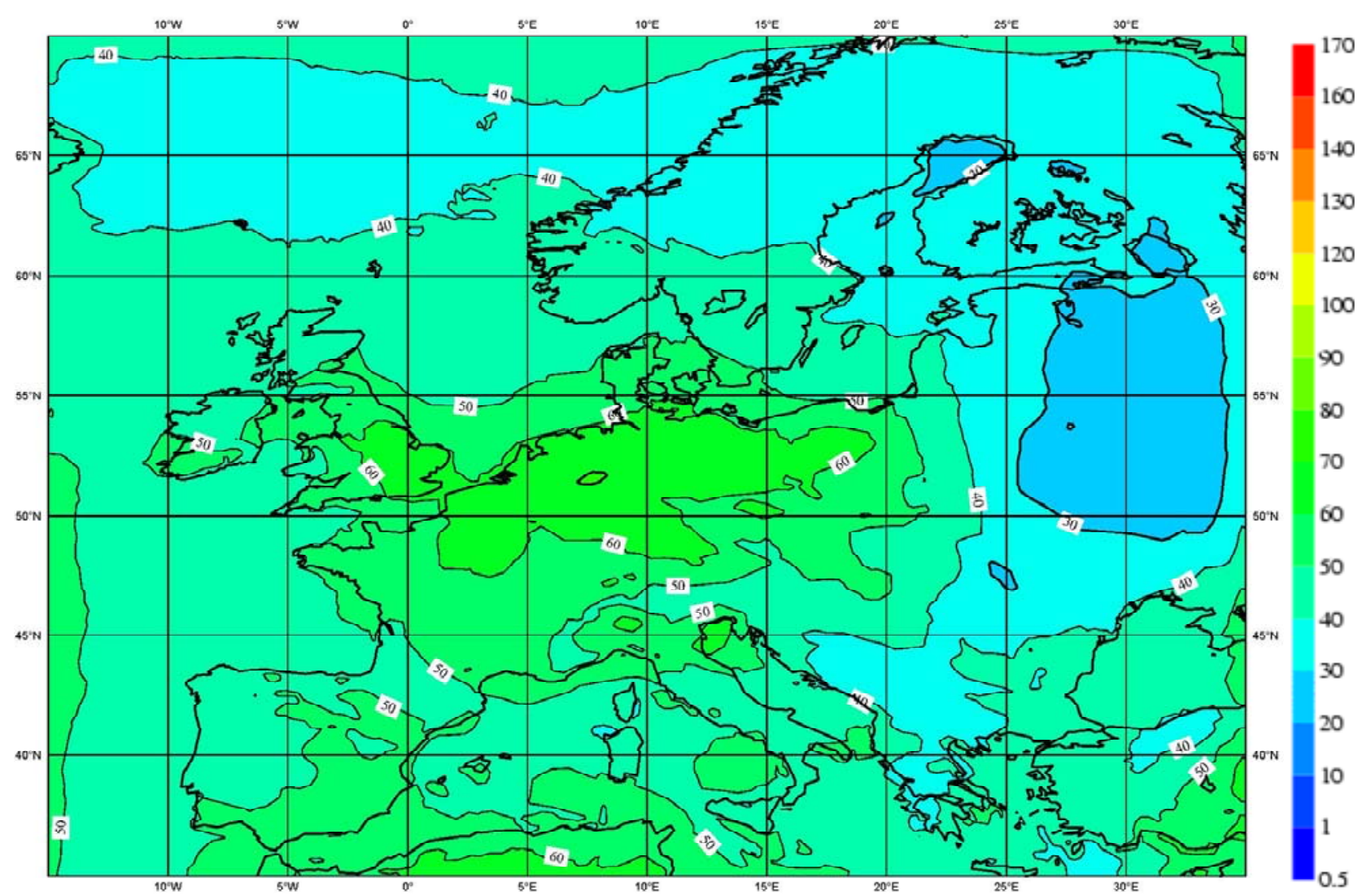

(a)

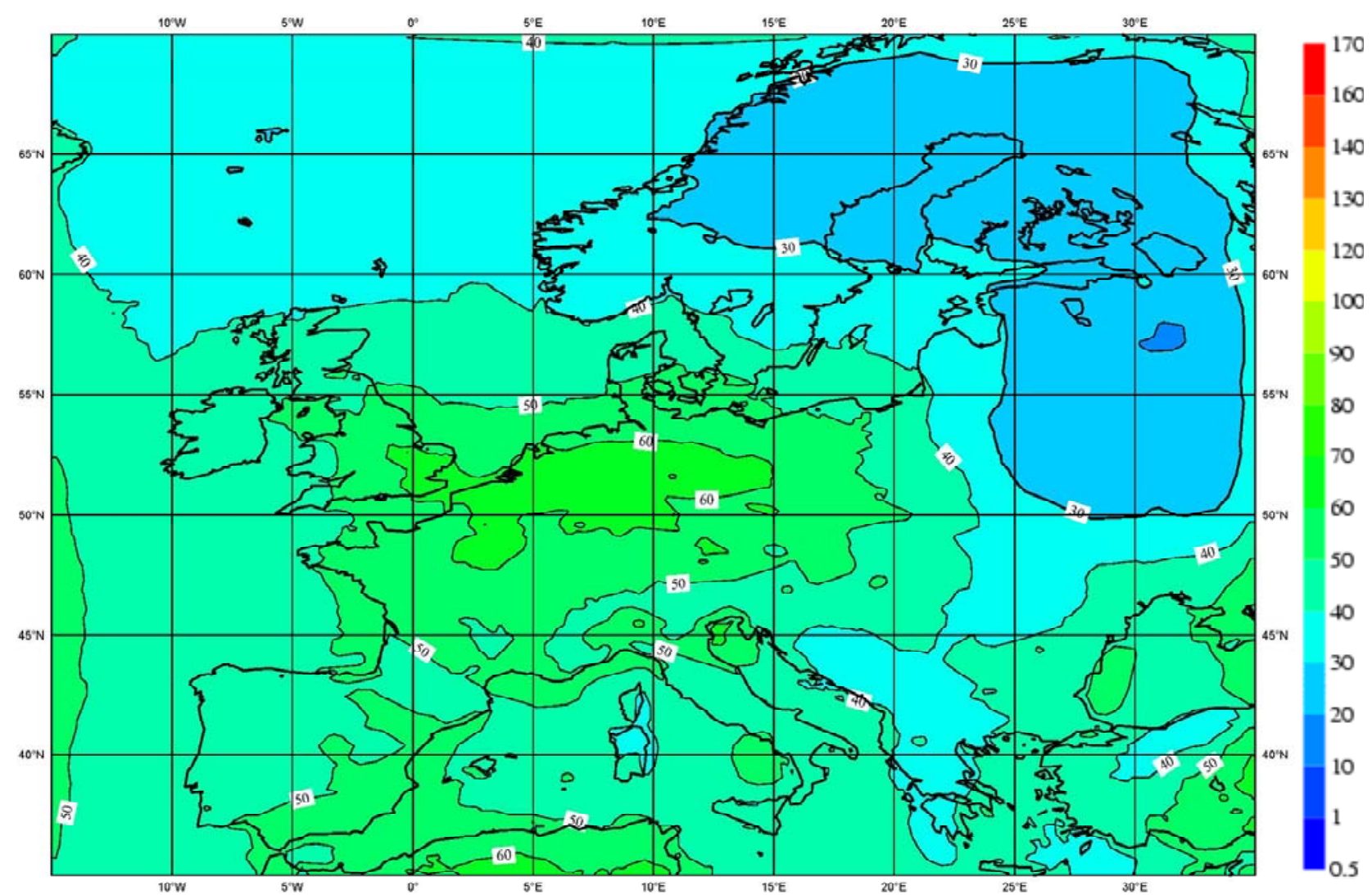

(b) 


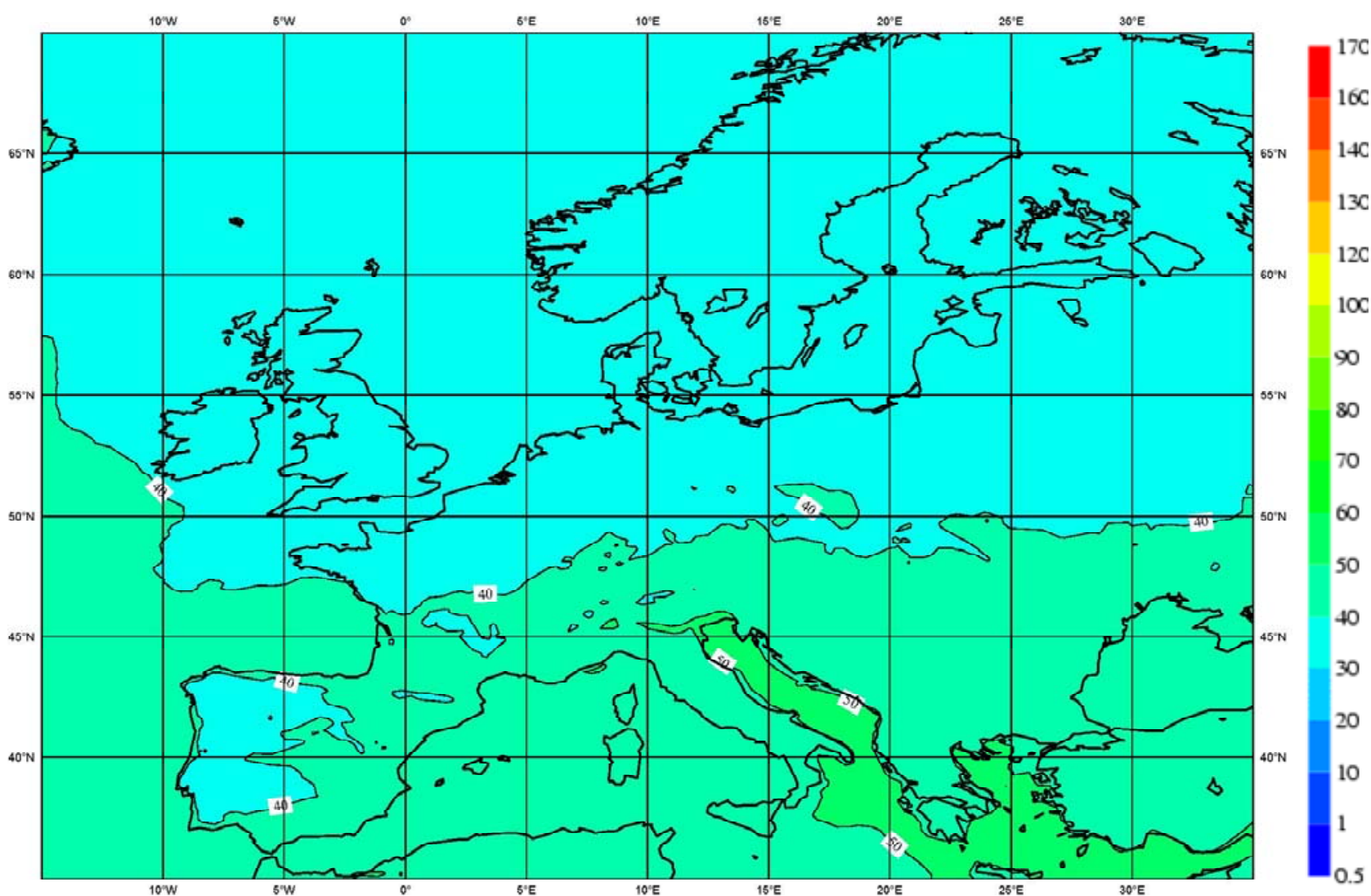

(c)

Figure 6. Averaged ozone concentrations (in $\mu \mathrm{g} / \mathrm{m}^{3}$ ) for (a) June; (b) summer and (c) winter 2000 (simulated by HIRLAM + CAMx).

of Denmark and border regions with Germany). The territories southerly of Denmark have higher ozone levels (above $60 \mu \mathrm{g} / \mathrm{m}^{3}$ ). These are associated with the ReinRuhr industrialized region and London metropolitan areas which are both located in a relative proximity to Denmark; and hence, polluted air masses can be transboundary transported toward Denmark.

The simulated seasonally-averaged patterns over the European domain, with a focus on territory of Denmark, were also analyzed. During spring the averaged ozone concentration over Denmark varied between 40 - 50 $\mu \mathrm{g} / \mathrm{m}^{3}$. The large area of the inland industrialized areas of France, Benelux countries, Germany, Po Valley (Italy) is associated with concentration higher than $50 \mu \mathrm{g} / \mathrm{m}^{3}$. The concentration less than $40 \mu \mathrm{g} / \mathrm{m}^{3}$ is observed over the large parts of the Scandinavia, Baltic States, Belorussia, and North-West Russia. During summer (Figure 6(b)), the situation is changed. In Denmark, the concentration has increased above $50 \mu \mathrm{g} / \mathrm{m}^{3}$ for Zealand, Fyn and southern Jutland, except the northern and central parts of the Jutland Peninsula. The total area with the ozone level of $50 \mu \mathrm{g} / \mathrm{m}^{3}$ expanded by almost a factor of 2 , and it is more extended in the longitudinal compared latitudinal direction. The Rein-Ruhr area become more visible (above 60 $\left.\mu \mathrm{g} / \mathrm{m}^{3}\right)$ as well as the London and Paris metropolitan areas compared with others. The lower ozone (below $30 \mu \mathrm{g} / \mathrm{m}^{3}$ ) is observed over the central and northern territories of the Scandinavia, and partially over the Baltic States and NorthWest Russia.

During fall, for the entire territory of Denmark the ozone level is slightly above $40 \mu \mathrm{g} / \mathrm{m}^{3}$. Ozone is about 40 $\mu \mathrm{g} / \mathrm{m}^{3}$ over territories southerly of Denmark and within the $0-15^{\circ} \mathrm{E}$ longitudinal belt. The area with ozone level below $30 \mu \mathrm{g} / \mathrm{m}^{3}$ moved far northward compared with summer; and it covers only central and northern territories of Sweden and Finland as well as Karelia and Kola Peninsula of Russia. As seen in Figure 6(c), during winter the ozone concentration is the lowest (below $30 \mu \mathrm{g} / \mathrm{m}^{3}$ ) compared with other seasons analyzed. Such levels are also characteristics for the territories of European countries situated northerly $50^{\circ} \mathrm{N}$.

On an annual scale, the averaged ozone concentration over Denmark varied between $40-50 \mu \mathrm{g} / \mathrm{m}^{3}$. The lowest concentration is observed for the central territories (around $65 \pm 2^{\circ} \mathrm{N}$ ) of Scandinavia. For inland territories of the majority of the European countries (except the Baltic States, Belorussia, and Russia) the ozone levels are above $40 \mu \mathrm{g} / \mathrm{m}^{3}$. The Rein-Ruhr and Po Valley Industrial 
areas have higher ozone levels of about $50 \mu \mathrm{g} / \mathrm{m}^{3}$.

\section{Conclusions}

In this study, three Danish measurement sites having the longest time-series of ozone measurements (with a time resolution of 1 hour and started in early 1990s) were evaluated-Ulborg (DK31); and Frederiksborg (DK32) and Lille Valby (DK41). These sites are located on the Jutland Peninsula and Zealand Island of Denmark. After pre-screening of the time series covering almost 15 year period, it has been analysed on inter-annual, monthly and diurnal cycle scales with more detailed evaluation of cases characterized by elevated and lowered ozone concentrations. Both the atmospheric Lagrangian trajectory (HYSPLIT) and Eulerian dispersion (HIRLAM + CAMx) models were employed to study dominating atmospheric transport patterns (attributed to sectors) associated with elevated ozone events and to evaluate spatio-temporal variability of ozone concentration patterns for selected elevated episode in Jun 2000 and comparison with monthly (Jun) and seasonal patterns for Denmark.

It was found that ozone inter-annual variability showed generally a positive trend, and the number of cases with low ozone concentration (less than $10 \mu \mathrm{g} / \mathrm{m}^{3}$ ) continued to diminish, and in particular, is has decreased almost twice. Monthly ozone variability showed clear differences between measurements on Jutland vs Zealand. The highest mean concentrations are observed in May for all sites. The mean concentrations are the lowest in November-December. The elevated concentrations (more than $120 \mu \mathrm{g} / \mathrm{m}^{3}$ ) are observed during March-September, and number of such cases is larger for Jutland (with maximum in August). On a diurnal cycle, ozone above 120 $\mu \mathrm{g} / \mathrm{m}^{3}$ is observed mostly during $13-16$ of local time, and the number of such cases is ten-fold larger compared with nighttime-early morning hours.

For all ozone elevated cases (in total, 506), using trajectory analysis, several sectors or pathways of atomspheric transport were identified. Depending on the geographical position of the site, up to $39 \%$ of elevated events can be associated with transport from the northwestern sector, from southern and south-eastern-22\% each, eastern- $18 \%$, and from south-western and northern sectors-13\% each. Among trajectories associated with elevated ozone levels, most of them travelled through inland (i.e. through the Baltic States, Russia, Poland, Germany, France, Benelux and Scandinavian countries) as well as over water areas (i.e. transport from the Atlantic Ocean, Baltic and North Seas).

Among ozone elevated events, less than 60 events for each site showed very high ozone concentrations (i.e. above $180 \mu \mathrm{g} / \mathrm{m}^{3}$ ). Several long-term episodes with continuous elevated ozone levels were identified: 7 (in Jun 1996 and Jun 2000) and 5 (in Jul 1992 and Jun 2000) for the for Jutland and Zealand sites, respectively. One episode (19-21 Jun 2000) simultaneously registered at all three sites was studied in more details using the chemical transport model. This episode was characterized by low wind speed with atmospheric transport from the southsouthwestern sector (associated with Benelux and German urban areas), mostly cloud-free conditions, and multiple inversions within the boundary layer. Measurements and modeling (trajectory and dispersion) results showed a relatively good agreement, although some discrepancies in concentration could be attributed to a relatively low horizontal resolution of the model run. For comparison, at the same time the typical monthly (June) ozone concentration varied between $50-60 \mu \mathrm{g} / \mathrm{m}^{3}$ for northern vs. southern territories of Denmark. In spring and summer, the averaged ozone concentration varied 40 - 50 and above $50 \mu \mathrm{g} / \mathrm{m}^{3}$, respectively. In fall, it is slightly more than $40 \mu \mathrm{g} / \mathrm{m}^{3}$, and in winter-it is the lowest (less than $30 \mu \mathrm{g} / \mathrm{m}^{3}$ ) throughout the year.

The results of this study are applicable for evaluation of short- and long-term ozone effects on health of population in both urban and rural areas and impact on environment (agriculture, forest, etc. damage), estimation of exposure levels for elevated episodes, and decision and policy making

\section{Acknowledgements}

The research leading to these results has received funding from the European Union's Seventh Framework Programme FP/2007-2011 within the project MEGAPOLI, grant agreement No. 212520 (Megacities: Emissions, urban, regional and Global Atmospheric Pollution and climate effects, and Integrated tools for assessment and mitigation; http://megapoli.info), Danish strategic center CEEH, contract no 2104-06-0027 (Center for Energy, Environment and Health; http://ceeh.dk) and HIRLAM. The DMI CRAY supercomputing facilities have been used extensively in this study. Thanks to DMI Computer Department for technical support and advice. Thanks to Allan Gross (NERI, Denmark) for useful discussions. The authors gratefully acknowledge the NOAA Air Resources Laboratory (ARL) for the provision of the HYSPLIT transport and dispersion model and/or READY website (http://www.arl.noaa.gov/ready.html) used in this publication. The authors acknowledge use of the ECMWF meteorological data; DMI Danish synoptical data archives; NCEP Reanalysis data (provided by the NOAA/-OAR/ESRL PSD, Boulder, Colorado, USA; http://www.esrl.noaa.gov/psd), and TNO MEGAPOLI emission inventory.

\section{REFERENCES}

[1] A. W. Schmalwiesera, G. Schaubergera and M. Janouch, 
"Temporal and Spatial Variability of Total Ozone Content over Central Europe: Analysis in Respect to the Biological Effect on Plants," Agricultural and Forest Meteorology, Vol. 120, No. 1-4, 2003, pp. 9-26. doi:10.1016/j.agrformet.2003.08.008

[2] Ch. Vlachokostasa, S. A. Nastisb, Ch. Achillasa, K. Kalogeropoulosa, I. Karmirisc, N. Moussiopoulosa, E. Chourdakisa, G. Baniasa and N. Limperia, "Economic Damages of Ozone Air Pollution to Crops Using Combined Air Quality and GIS Modeling," Atmospheric Environment, Vol. 44, No. 28, 2010, pp. 3352-3361.

[3] A. R. MacKenziea, R. M. Harrison, I. Colbeckb, P. A. Clarkd and R. H. Varey, "The Ozone Increments in Urban Plumes," Science of The Total Environment, Vol. 159, No. 2-3, 1995, pp. 91-99. doi:10.1016/0048-9697(95)04312-O

[4] X. V. Francisa, C. Chemela, R. S. Sokhia, E. G. Nortonb, H. M. A. Rickettsb and B. E. A. Fisher, "Mechanisms Responsible for the Build-up of Ozone over South East England during the August 2003 Heatwave," Atmospheric Environment, Vol. 45, No. 38, 2011, pp. 6880-6890. doi:10.1016/j.atmosenv.2011.04.035

[5] J. Niatthijsen, P. J. H. Builtjes, E. W. Meijer and G. Boersen, "Modelling Cloud Effects on Ozone on a Regional Scale: A Case Study," Atmospheric Environment, Vol. 31, No. 19,1997 , pp. 3227-3238. doi:10.1016/S1352-2310(97)00064-2

[6] R. G. Derwenta, D. S. Stevensonc, W. J. Collinsb and C. E. Johnsonb, "Intercontinental Transport and the Origins of the Ozone Observed at Surface Sites in Europe," Atmospheric Environment, Vol. 38, No. 13, 2004, pp. 18911901. doi:10.1016/j.atmosenv.2004.01.008

[7] R. G. Derwent, "The Long Range Transport of Ozone within Europe and Its Control," Environmental Pollution, Vol. 63, No. 4, 1990, pp. 299-318. doi:10.1016/0269-7491(90)90137-2

[8] A. Mahura, R. Nuterman, I. Petrova and A. Gross, "Elevated Ozone Levels in Denmark: Analysis Employing Trajectory and Chemical Transport Modelling," Abstracts of the European Meteorological Society (EMS) Annual Meeting, Toulouse, 28 September-2 October 2009, p. 70.

[9] A. Mahura, R. Nuterman, I. Petrova and B. Amstrup, "Potential Source Regions for Elevated Ozone Events in Denmark," Abstracts of the European Geosciences Union (EGU) General Assembly, Vienna, 2-7 May 2010, p. 11374.

[10] A. Stohl, "Computation, Accuracy and Applications of Trajectories-A Review and Bibliography," Atmospheric Environment, Vol. 32, No. 6, 1998, pp. 947-966. doi:10.1016/S1352-2310(97)00457-3

[11] R. R. Draxler and G. D. Rolph, "HYSPLIT-Hybrid Single-Particle Lagrangian Integrated Trajectory Model," NOAA Air Resources Laboratory, Silver Spring, 2003. http://www.arl.noaa.gov/ready/hysplit4.html

[12] G. D. Rolph, "Real-Time Environmental Applications and Display System (READY) Website," NOAA Air Re- sources Laboratory, Silver Spring, 2003.

http://www.arl.noaa.gov/ready/hysplit4.html

[13] E. Kalnay, M. Kanamitsu, R. Kistler, W. Collins, D. Deaven, L. Gandin, M. Iredell, S. Saha, G. White, J. Woollen, Y. Zhu, A. Leetmaa, R. Reynolds, M. Chelliah, W. Ebisuzaki, W. Higgins, J. Janowiak, K. C. Mo, C. Ropelewski, J. Wang, R. Jenne and D. Joseph, "The NCEP/ NCAR 40-Year Reanalysis Project," Bulletin of the American Meteorological Society, Vol. 77, No. 3, 1996, pp. 437-470. doi:10.1175/1520-0477(1996)077<0437:TNYRP $>2.0 . C O$ ;2

[14] X. Yang, C. Petersen, B. Amstrup, B. Andersen, H. Feddersen, M. Kmit, U. Korsholm, K. Lindberg, K. Mogensen, B. H. Sass, K. Sattler and N. W. Nielsen, "The DMIHIRLAM Upgrade in June 2004," DMI Technical Report, No. 05-09, 2005, p. 35.

[15] P. Unden, L. Rontu, H. Jarvinen, P. Lynch, J. Calvo, G. Cats, J. Cuxart, K. Eerola, C. Fortelius, J. A. GarciaMoya, C. Jones, G. Lenderlink, A. McDonald, R. McGrath, B. Navascues, N. W. Nielsen, V. Degaard, E. Rodriguez, M. Rummukainen, R. Room, K. Sattler, B. H. Sass, H. Savijarvi, B. W. Schreur, R. Sigg, H. The and A. Tijm, "HIRLAM-5 Scientific Documentation," Swedish Meteorological and Hydrological Institute, Norrköping, 2002.

[16] H. Savijärvi, "Fast Radiation Parameterization Schemes for Mesoscale and Short-Range Forecast Models," Journal of Applied Meteorology, Vol. 29, No. 6, 1990, pp. 437-447.

[17] G. Lenderink and A. A. M. Holtslag, "An Updated Length-Scale Formulation for Turbulent Mixing in Clear and Cloudy Boundary Layers," Quarterly Journal of the Royal Meteorological Society, Vol. 130, No. 604, 2004, pp. 3405-3427. doi:10.1256/qj.03.117

[18] J. Noilhan and S. Planton, "A Simple Parameterization of Land Surface Processes for Meteorological Models," Monthly Weather Review, Vol. 117, No. 3, 1989, pp. 536549.

[19] M. W. Gery, G. Z. Witten, J. P. Killus and M. C. Dodge, "A Photochemical Kinetics Mechanism for Urban and Regional Scale Computer Modelling," Journal of Geophysical Research, Vol. 94, No. D10, 1989, pp. 925-956. doi:10.1029/JD094iD10p12925

[20] S. Madronich, "The Prohospheric Visible Ultra-Violet (TUV) Model Webpage," National Center for Atmospheric Research, Boulder, 2002. http://cprm.acd.ucar.edu/Models/TUV/

[21] J. Kuenen, H. Denier van der Gon, A. Visschedijk, H. van der Brugh, S. Finardi, P. Radice, A. d'Allura, S. Beevers, J. Theloke, M. Uz-basich, C. Honoré and O. Perrussel, “A Base Year (2005) MEGAPOLI European Gridded Emission Inventory (Final Version). Deliverable D1.6," MEGAPOLI Scientific Report 10-17, 2010, p. 39. 